\title{
RE-CONCEPTUALIZING THE RIGHT OF SILENCE AS AN EFFECTIVE FAIR TRIAL STANDARD
}

\author{
JOHN JACKSON*
}

\begin{abstract}
As the European Court of Human Rights has come to qualify the privilege against self-incrimination and the right of silence in recent decisions, this article argues that the Court has failed to provide a convincing rationale for these rights. It is claimed that within the criminal process the right of silence should be distinguished from the privilege against selfincrimination and given enhanced effect in order to uphold the protective and participatory rights of the defence which come into play when a suspect is called upon to answer criminal allegations.
\end{abstract}

\section{INTRODUCTION}

When the European Court of Human Rights in Funke v France ${ }^{1}$ gave expression to the right of anyone charged with a criminal offence to remain silent and not to contribute to incriminating himself. This was an important symbolic statement of the importance of the right across European jurisdictions straddling both common law and civil law traditions. The right had, of course, been entrenched in a number of international instruments such as the Universal Declaration of Human Rights (UNDHR), the International Covenant on Civil and Political Rights (ICCPR) and the American Convention on Human Rights (ACHR) and although there is no explicit reference to the privilege in article 6 of the ECHR, the Committee of Experts which reported to the Committee of Ministers of the Council of Europe on the differences between the ICCPR and ECHR in 1970 had considered that prohibition of self-indictment was of the 'very essence' of a fair trial. ${ }^{2}$ The European Court of Justice had also recognized the right in an important judgment in $1989 .^{3}$ But the Funke decision was the first occasion when the Strasbourg court affirmed the significance of the right.

* School of Law, University College Dublin. This paper was substantially written during the course of a British Academy research leave fellowship from October 2006-September 2008 and while I was a Senior Fernand Braudel Fellow at the European University Institute in Florence from October 2007-June 2008. Thanks are due to participants at the Conference on Criminal Justice in Crisis at the School of Law, University of Aberdeen 17-18 October 2008 for comments and criticisms and to Sarah Summers for comments on an earlier draft. Email: john.jackson (a) ucd.ie.

1 Funke v France (1993) 16 EHRR 297.

2 Report of the Committee of Experts on Human Rights to the Committee of Ministers (Strasbourg, Council of Europe, 1970) para 141 (vi).

${ }^{3}$ Case 374/87 [1989] Orkem v European Commission, ECR 3283. 
More recently, however, the Strasbourg court would seem to have diminished its importance by indicating in cases such as Jalloh $v$ Germany ${ }^{4}$ and O'Halloran and Francis $v$ United Kingdom ${ }^{5}$ that the right is not absolute and that a range of factors can be taken into account in determining whether the privilege against self-incrimination will apply in a particular case. More worryingly, the Court in Jalloh suggested that competing public interests such as the urgent need to obtain evidence may even be taken into account in determining whether certain treatment amounted to inhuman and degrading treatment. At a time when the Court appears more ready to countenance public interest arguments to dilute the force of the individual rights in the Convention, it would seem to be more important than ever to have a clear view of what the rights are for.

Yet the rationale for the privilege against self-incrimination has always been difficult to justify precisely. In the United States an increasing number of commentators have expressed a declining faith in the rationale for the selfincrimination clause of the Fifth Amendment. It has been described variously as 'an unsolved riddle of vast proportions, a Gordian knot in the middle of our Bill of Rights ${ }^{6}$ and a doctrine which cannot be 'squared with any rational theory', 7 relying for its justification on 'stirring rhetoric that may move the heart but leaves the intellect unconvinced', the fundamental values said to underpin it being striking in their 'vacuity and circularity'. ${ }^{8}$ In this article it will be argued that the rationales used by the European Court are equally unconvincing. Part of the difficulty it will be argued is that there has been a failure to differentiate clearly enough between the substantive and procedural dimensions of the right. The case law of the Court has focused more on those aspects of the right to do with upholding the dignity and will of the individual accused than on the more procedural aspects of the right which link it to defence rights when a suspect or accused is called upon to answer criminal allegations. ${ }^{9}$ While the substantive dimensions may be subject to proportionate curtailment, the procedural dimensions have at their root a need to enable the accused to mount an effective defence which cannot be balanced away against other considerations. It will be claimed that within the criminal process

4 (2007) 44 EHRR 32.

5 Application nos. 15809/02 and 25624/02, 29 June 2007.

6 AR Amar and RB Lettow, 'Fifth Amendment, First Principles: The Self-Incrimination Clause' (1995) 93 Michigan Law Review 857, quoted in R J Allen and M K Mace, 'The SelfIncrimination Clause Explained and its Future Predicted' (2004) 94 Journal of Criminal Law \& Criminology 243, 245.

7 W J Stuntz, 'Self-Incrimination or Excuse' (1988) 88 Columbia Law Review 1227, 1228, quoted in Allen and Mace, ibid. See also D Dolinko, 'Is There a Rationale for the Privilege Against Self-Incrimination?' (1986) 33 UCLA Law Review 1063.

8 Allen and Mace (n 6) 244.

9 See also S J Summers, Fair Trials: The European Criminal Procedural Tradition and the European Court of Human Rights (Hart, Oxford, 2007) 161-2 (arguing that the focus in the Court's case law on the autonomy of the accused neglects the importance of the defence role in the institutional understanding of fairness). 
the right of silence in particular is entitled to be given an enhanced effect not specifically for reasons to do with upholding substantive rights such as the dignity and respect of the individual but in order to uphold the procedural rights of the defence which come into play when a suspect is called upon to answer criminal allegations.

The article is in three parts. First, it will trace the recent jurisprudence of the Court to show how the right has been diluted in recent decisions. Second, it will examine the rationales put forward by the Court. Third, it will identify the need to focus upon the procedural dimensions of the right.

\section{THE APPROACH OF THE COURT TOWARDS THE PRIVILEGE AGAINST SELF-INCRIMINATION}

Although Funke v France did much to signal the importance of the right, it was not until the later case of Saunders $v$ United Kingdom ${ }^{10}$ that the Court gave greater clarity to its precise scope. The Court emphasized, first of all, that the privilege against self-incrimination and the right of silence were generally recognized international standards which lay at the heart of the notion of a fair trial procedure. But it was a right that was confined for the purposes of Article 6 of the ECHR to persons charged with criminal proceedings which, of course, is given an autonomous meaning within the ECHR system. It was also primarily concerned with respecting the will of an accused person to remain silent and did not extend to the use in criminal proceedings of material obtained from the accused through the use of compulsory powers, but which has an existence independent of the will of the suspect, such as documents pursuant to a warrant, breath, blood and urine samples and bodily tissues for the purpose of DNA testing. At the same time the privilege extended not just directly to protect suspects from incriminating themselves but also indirectly to the use of self-incriminating information against them at their trial.

The Court did not find it necessary in Saunders to decide whether the right was absolute or whether infringements may be justified in particular circumstances. In the earlier case of John Murray $v$ United Kingdom ${ }^{11}$ it had made it clear that warning suspects that adverse inferences may be drawn against them at their trial amounted to an indirect form of compulsion which did not necessarily destroy the very essence of the privilege. But in Saunders the Court did not accept the government's argument that the privilege could be balanced away on some pressing ground of public interest such as the need to investigate and punish fraud. The fairness requirement of Article 6 meant that the privilege applied to all types of criminal proceedings without distinction from the most simple to the most complex. In Heaney and McGuinness $v$ Ireland $^{12}$ the Court took the view that compelling persons to account for their 
movements in the interests of averting terrorism under the Offences Against the State Act did destroy the very essence of the privilege and the security and public order concerns of the government could not justify a provision which extinguished this essence.

This approach suggests that when an infringement goes to the 'essence of the privilege' it can never be justified whatever the countervailing public interest considerations. But in Jalloh the Court cast doubt on this by suggesting that in determining whether the proceedings as a whole have been fair, the Court will weigh the public interest in the investigation and punishment of the offence against the individual interest that the evidence has been gathered lawfully. ${ }^{13}$ In this case emetics was forcibly administered to the applicant after he was seen to swallow a tiny plastic bag or bubble thought to contain drugs when he was approached by police officers. The applicant was a street dealer who was offering drugs for sale on a comparably small scale and was finally given a six-month suspended prison sentence and probation. As a result the public interest in securing the applicant's conviction could not justify recourse to such a grave interference with his physical and mental integrity. But in applying this balancing test, the Court left open the possibility that the privilege could be infringed in the public interest, something that seemed to be precluded in Saunders and Heaney and McGuinness, thus adding some uncertainty to the scope of the privilege.

Apart from the question of the weight of the public interest in the investigation and punishment of the offence, the Court in Jalloh mentioned a number of other factors to be taken into account in determining whether the right not to incriminate oneself has been violated: the nature and degree of the compulsion, the existence of relevant safeguards in the procedure and the use to which any material so obtained is put. ${ }^{14}$ In John Murray the Court had already made a distinction between direct and indirect compulsion and indicated that a certain amount of indirect compulsion was acceptable. In Jalloh there is also the suggestion that if there are relevant safeguards in the procedure, these may be enough to offset a finding that there has been a violation of the privilege. The Court observed that section 81a of the German Code of Criminal Procedure provided that bodily intrusions had to be carried out lege artis by a doctor in a hospital and only if there was no risk of damage to the defendant's health. In this case, however, the applicant refused to submit to a prior medical examination. He could only communicate in broken English which meant that he was subjected to the procedure without a full examination of his physical aptitude to withstand it. This, however, raises the question whether the Court might have been prepared to consider that there was no violation of the privilege if he had been subjected to a proper medical examination. It is hard to see how safeguards to protect the applicant's physical health could affect

13 (2007) 44 EHRR 32. para 117.

14 ibid, para 44. 
the essence of the privilege which the Court has said it is primarily concerned with respecting the will of the accused. The suggestion that there may be compensating safeguards which may be enough to offset the privilege also raises questions about how significant the privilege is in the first place.

Finally, the Court's reference to the use to which any material obtained is put as a factor in determining whether the right against self-incrimination has been violated suggests that there may be circumstances when the Court may consider that incriminating material may be used against the accused at trial. This would seem to contrast with Judge Morenilla's view in Saunders that the very fact that the applicant's compelled statements had been admitted in evidence against him undermined the very essence of his right not to incriminate himself. $^{15}$ In Jalloh the Court stated that the drugs obtained following the administration of the emetics were the decisive evidence in the applicant's conviction for drugs-trafficking, thereby suggesting an analogy with the way in which the Court approaches the testimony of witnesses whom the accused has had no opportunity of examining. ${ }^{16}$ It is to be noted that the question here is not a legal question requiring some judgment to be made about the importance of the privilege against other principles or public interests. It is more a factual question whether in the light of other evidence in the trial, the selfincriminating aspect could not be considered significant and therefore to have affected the overall fairness of the trial. Other questions that are raised by this approach are whether the use of derivative evidence obtained as a result of the information provided under compulsion can be used against the accused or whether the use of the incriminating material to impeach the accused's evidence or another witness might be acceptable as an alternative to using the evidence directly against the accused. ${ }^{17}$

Instead of re-affirming an approach that would justify certain infringements of the privilege only where they do not go to the 'essence of the privilege', Jalloh seemed to embark on a 'wholly new approach' whereby a wide range of factors may be considered in deciding whether a particular instance of selfincrimination constitutes a violation. ${ }^{18}$ This approach was re-affirmed by the Grand Chamber in O'Halloran and Francis ${ }^{19}$ which held it could not accept that any direct compulsion requiring an accused person to make incriminatory statements automatically violated the privilege against self-incrimination. The central issue in each of two applications brought in this case was whether the privilege was violated when the registered keeper of a car was required

15 (1997) 23 EHRR 313, concurring opinion.

16 cf Kostovski v Netherlands (1991) 12 EHRR 434, para 44.

17 See M Boyle, 'Freedom from Self-Incrimination and the Right of Silence: A Pandora's Box?' in Mahoney et al (eds), Protecting Human Rights: the European Perspective (Carl Heymanns Verlag, Cologne, 2000) 1021, 1029-30.

18 This was the view of the dissenting judge, Judge Pavlovschi, in O'Halloran and Francis $v$. UK (2008) 46 EHRR 21 (Application no 15809/02). See also A Ashworth, Commentary [2007] Crim LR 897. 
under United Kingdom road traffic law to furnish the name and address of the driver of the car when it was caught speeding on camera. The first applicant, O'Halloran, admitted he was the driver on the occasion in question and he had argued unsuccessfully at his trial that his confession should be excluded because his privilege against self-incrimination had been violated. The second applicant, Francis, on the other hand, was convicted for refusing to supply the information required. Although the Court did not go so far as Jalloh and indeed earlier UK authority ${ }^{20}$ which suggested that the privilege could be balanced away on broad public interest grounds, it followed Jalloh by referring to the other factors mentioned in that case which could be taken into account in order to determine whether the privilege was infringed such as the nature and degree of the compulsion used to obtain the evidence, the existence of any relevant safeguards in the procedure and the use to which any material so obtained was put. The Court concluded that having regard to these factors, the essence of the applicants' right to remain silent and their privilege against self-incrimination had not been destroyed.

As regards the nature and degree of the compulsion used to obtain the evidence, the Court referred to Lord Bingham's opinion in the Privy Council case of Brown $v$ Stott $^{21}$ that all who own or drive motor cars know that they are subject to a regulatory regime which requires them to disclose certain information in the interest of public safety. A further aspect of the compulsion applied in the present case was that the information required was limited only as to the identity of the driver. As regards the relevant safeguards, the compulsion was subject to the safeguard that no offence was committed if the owner could show that he did not know and could not with reasonable diligence have known who the driver of the vehicle was. As to the use to which the statements were put, the identity of the driver was only one element in the offence of speeding and conviction for such an offence did not arise solely from the information obtained and in the case of Francis who refused to give the information in the first place, this constituted the offence itself.

The difficulty with all these factors is that they do not appear to be particularly cogent as a means of distinguishing the facts from other cases where the Court has held that there was a violation of the privilege. Although it may be relevant to distinguish cases where persons voluntarily engage in certain activities such as driving and it may be justified to place certain obligations on them such as the need to obtain and carry a licence, it can hardly be said, as one of the dissenting judges put it, that all those who own or drive cars are automatically presumed to have given up unambiguously and unequivocally the right to remain silent. ${ }^{22}$ Even if this could be said, it would seem equally

\footnotetext{
20 See Brown v Stott [2001] 2 WLR 817 (holding that the power to require owners to name drivers was not a disproportionate response to the general public interest in maintaining public safety).

21 [2001] 2 WLR 817.

22 See dissenting opinion of Judge Myjer in O'Halloran and Francis.
} 
to follow that those like Saunders who voluntarily engage in corporate activity must also be presumed to have given up their right to silence in relation to the investigation and prosecution of matters associated with these activities-but this is not what the majority of the Court presumed in Saunders. The point that all that was being asked of car owners in this case was to provide one simple fact may be answered on the ground that the disclosure of one simple fact may be devastating in terms of one's incrimination in an offence. The fact that owners were exonerated when they could not with reasonable diligence have known who the driver of their car was goes more to the principle of nullum crimen sine culpa than to the principle of self-incrimination. Finally, the fact that the use made of the incriminating statement was not enough in itself to convict one of the offence does not make the statement any the less incriminating and the fact that one can be prosecuted and sentenced to a considerable fine for reliance on the privilege appeared to the Court in Heaney and McGuinness to destroy the very essence of the privilege.

\section{RATIONALE OF THE PRIVILEGE AND THE RIGHT OF SILENCE}

The degree to which limitations may be put upon the exercise of the privilege would seem to depend on how significant the privilege is considered to be. We have seen that the Court has linked the privilege and the right of silence very closely to the aims of a fair trial, putting them at the heart of a fair procedure. This would seem to suggest that the right is primarily a procedural right attached to the right to a fair trial rather than a substantive right expressing the principle that individuals generally should not have to account to the State for their actions or activities. In an earlier case pre-dating Funke, the European Commission had recognized a general right of silence as the negative counterpart of the right to freedom of expression enshrined in article 10 of the ECHR. ${ }^{23}$ Applying the broader balancing test required under article 10 the Commission considered that while there were situations when a person could be compelled to speak when there is a basis in law, a legitimate aim and a pressing social need for compulsion such as when witnesses are required to testify, when persons are required to incriminate themselves out of their own mouth this involves a particular intrusion on individuals which is entitled to a particular weighting. This broader right of silence is not one that was pursued in the jurisprudence and the right has been linked instead to the fair trial right under article 6.

At first sight it seems strange to say that the privilege and the right of silence lie at the heart of a fair procedure as they prescribe negatively what constitutes an unfair procedure without positively setting out what is a fair procedure. ${ }^{24}$

\footnotetext{
${ }^{23} K v$ Austria Series A no 255-B, 2 June 1993.

24 S Trechsel, Human Rights and Criminal Proceedings (Oxford University Press, Oxford, 2005) 347-8.
} 
The reasons why the Court considers the rights to be so important are to be found in a passage in Saunders which has been restated in a number of subsequent judgments: ${ }^{25}$

Their rationale lies, inter alia, in the protection of the accused against improper compulsion by the authorities thereby contributing to the avoidance of miscarriages of justice and to the fulfilment of the aims of Article $6 \ldots$ The right not to incriminate oneself, in particular, presupposes that the prosecution in a criminal case seek to prove their case against the accused without resort to evidence obtained through methods of coercion or oppression in defiance of the will of the accused. In this sense the right is closely linked to the presumption of innocence contained in Article 6.2 of the Convention.

The right not to incriminate oneself is primarily concerned, however, with respecting the will of an accused person to remain silent.

Although the Court links the rights to a fair procedure suggesting the rights are fundamentally about procedural fairness, in fact there are two kinds of rationales mentioned here which are mixed together somewhat: what has been described as an intrinsic substantive rationale that it is in principle unfair to require accused persons to do anything that might incriminate themselves and a non-substantive rationale which claims that the requirement offends other basic rights and principles associated with a fair trial such as the presumption of innocence and the need to avoid miscarriages of justice. ${ }^{26}$

The intrinsic substantive rationale which would seem to be the primary concern links the rights to the idea of respect for the will of the accused. This would seem to be an expression of the principle that any positive participation by the accused in the criminal process must be on a voluntary basis. One of the difficulties here, however, is in determining when participation is voluntary and when it is not. Arguably, persons facing criminal allegations are placed in a position where their freedom to choose whether to speak or not is extremely limited, all the more so when they are being questioned by the police in custody. More fundamentally, however, a number of commentators ${ }^{27}$ have found it difficult to justify why there should be a special right to protect accused persons from being required to incriminate themselves. Accused persons are already protected under the ICCPR, the ACHR and the ECHR in

25 (1997) 23 EHRR 313, paras 68-69; Serves v France (1999) 28 EHRR 265, para 46; Quinn v Ireland (2001) 33 EHRR 264, para 40; Heaney and McGuinness v Ireland (2001) 33 EHRR 12, para 40; Allan v United Kingdom (2003) 36 EHRR 12; JB v Switzerland Appl 31827/96 (2001), para 64; Jalloh $v$ Germany (2007) 44 EHRR 32, para 100.

26 This useful distinction has been made by D McGrath, Evidence (Thomson Round Hall, Dublin, 2005) 623. See also I Dennis, 'Instrumental Protection, Human Right or Functional Necessity? Reassessing the Privilege Against Self-Incrimination' (1995) 54 CLJ 342, 348 (making a distinction between theories concerned with 'accusatorial process norms' and theories concerned with upholding substantive values).

27 See eg RJ Allen, 'The Simpson Affair, Reform of the Criminal Justice Process and Magic Bullets’ (1996) 67 University of Colorado Law Review 988, 1021 and Dolinko (n 7). 
an absolute way from being forced to confess by the requirement that they are not be subjected to torture, cruel, inhuman or degrading treatment. In addition persons are protected in the criminal process, although not in an absolute way, by a right to privacy and as we have seen arguably under Article 10 by a general right of silence. So what is it that justifies the additional protection from being required to incriminate oneself within the criminal process?

According to critics, we have to fall back here on the 'old woman's reason' given by Bentham that it is harsh to subject accused persons to the burden of self-incrimination or, as the US Supreme Court has put it, to the 'cruel trilemma of self-accusation, perjury or contempt' ${ }^{28}$ Of course, in the reality of modern criminal justice systems, this trilemma is not so painful as is suggested here. As a general rule defendants are not prosecuted for refusing to answer questions before trial and at trial are never prosecuted for contempt for failing to testify. The modern debate in many jurisdictions is instead directed to whether adverse evidential consequences should attach to silence. ${ }^{29}$ In telling lies there is the risk that one might be caught out but this takes us to the nub of the point made by many critics that the trilemma, if it is a trilemma, is only faced by guilty persons. ${ }^{30}$ Martens $J$ made this point forcibly in his dissenting opinion in Saunders ${ }^{31}$ when he said that this rationale cannot justify the immunities under discussion since they presuppose that the suspect is guilty, 'for an innocent person would not be subjected to such choices nor bring about his own ruin by answering questions truthfully'. Consequently, innocent suspects are not treated 'cruelly or unethically, whilst guilty suspects should not complain that society does not allow them to escape conviction by refusing to answer questions or otherwise hiding evidence'.

Mike Redmayne has suggested that we should not be too quick to accept these counter-arguments. ${ }^{32}$ He argues that the privilege against selfincrimination is grounded in the idea that in a liberal democracy citizens are entitled to distance themselves from prosecutions as this is when the State is at its most powerful. Distinctions based on the guilty and the innocent imply that there is no value in protecting a guilty person from self-incrimination. Yet we should recognize the particular harm which is done to personal integrity when the State requires us to incriminate ourselves in the course

28 Murphy v Waterfront Commission (1964) 378 US 52, 55, per Goldberg J. For a clear analysis of Bentham's arguments, see W Twining, Theories of Judicial Evidence: Bentham and Wigmore (Weidenfeld \& Nicolson, London, 1983) 84.

${ }^{29} \mathrm{P}$ Roberts and A Zuckerman, Criminal Evidence (Oxford University Press, Oxford, 2005) 395.

30 R J Allen, 'The Simpson Affair, Reform of the Criminal Justice Process and Magic Bullets' (1996) 67 University of Colorado Law Review 989, 1021.

31 (1996) 23 EHRR 313, para 9, n 74.

32 M Redmayne, 'Rethinking the Privilege Against Self-Incrimination' (2007) 27 Oxford Journal of Legal Studies 209, 221. 
of a prosecution. ${ }^{33}$ Conversely, the argument that the innocent are never subjected to cruel choices is also over-stated. As Redmayne has pointed out, imposing a duty to cooperate may sometimes confront innocent persons with difficult choices as where one may compelled to incriminate others who are close to us. ${ }^{34} \mathrm{He}$ gives the example of the owner of a car asked to identify the person driving his car. If he was not driving then it was another person, presumably a friend. As Redmayne recognizes, however, the same dilemma confronts witnesses who are compelled to testify against an intimate person. We ought not lightly to impose requirements on a person to testify against such a person but ultimately we consider that such arguments are counterbalanced by the need for the criminal justice system to have access to incriminating information. In a similar manner we should place some weight on the privilege against self-incrimination but it is hard to see why it should be given the special status of a fair trial right entitling suspects and defendants to a special immunity from being compelled to provide self-incriminating information which may be used against them.

Another problem with a rationale based on respecting the will of the accused is that it is difficult to find a clear and coherent dividing line between what State conduct may be said to respect the will and what does not. In his dissenting opinion in Saunders, Judge Martens questioned the distinction between the use of material obtained by legal compulsion such as blood and urine samples and the use of material obtained in defiance of the will. ${ }^{35}$ In both cases the will of the suspect is not respected in that he is forced to bring about his own conviction. The best interpretation of the distinction made by the Court is to be found by equating the privilege with an immunity from wilfully participating in one's own incrimination. This would include the handing over of documents but would not include submitting to blood tests, although certain decisions such as Jalloh do not seem to square with this. There is still a problem, however, in finding a rationale which views handing over documents as coming within the privilege but submitting to a blood test as outside the privilege. In each case there is compulsion in terms of restricting personal autonomy, in the one case by requiring the accused to act against his will and in the other by requiring that he submit to interference with his body. Thus the Supreme Court of Canada has recognized that the principle against self-incrimination applies to "products of the mind and products of the body'. 36

Some jurisdictions have tried to limit the compulsion to condemn oneself to testimonial rather than real evidence. This may seem an easier line to draw although it can still lead to fine distinctions such as what to do about lie

\footnotetext{
33 See also R K Greenawalt, 'Silence as a Moral and Constitutional Right' (1981) 23 William and Mary Law Review 15, 39.

34 Redmayne (n 31) 222.

${ }^{36} R v B(S A)$ [2003] 2 SCR 678, para 34. 
detection tests. ${ }^{37}$ But the difficulty remains that one can incriminate oneself in other ways than condemning oneself out of one's own mouth, and if the rationale for the principle is to be found in respecting the will of the suspect, why should these other forms of self-incrimination be excluded? One reason that has been given is that there is something inherently worse about the State invading the 'sanctum of the mind' for the purpose of incriminating an individual. ${ }^{38}$ Another point of difference is that real evidence is frequently more 'objective' and reliable with the result that it can be of considerable assistance in a criminal investigation. ${ }^{39}$ But these would seem to be arguments better made in the context of considering whether the privilege should be given more or less force to specific situations rather than for making hard and fast distinctions based on what should be included or excluded within the privilege. Thus although the Supreme Court of Canada has considered that body samples may come within the privilege, the key question is whether in each case the search for truth outweighs self-incrimination concerns about the abuse of state power. In $R \vee B(S A),{ }^{40}$ for example, the Court was asked to make DNA warrant legislation unconstitutional on the ground that a DNA sample was so intimately tied to one's person that the legislation effectively required one to incriminate oneself. The Court considered that DNA evidence was reliable and important evidence, unlike in the case of compelled statements which may well be untrue. On the other side, there was to be weighed the extent of compulsion being exercised, the degree to which the State and the suspect were in an adversarial position at the time the evidence was gathered, and any circumstances that might increase the risk of abuse of power including the degree of invasion required. Although the Court held that the degree of compulsion was great and the adversarial position high during a criminal investigation, the safeguards attached to a warrant and the relatively unobtrusive way DNA can be obtained lessened the risk of abuse of power to the point where the balance favoured discovering the truth over the selfincrimination concern of the accused. This principled approach towards selfincrimination is reminiscent of the kind of balancing exercise required in respect of a number of qualified rights under the Convention such as the right of privacy under article 8 and the freedom of expression under Article 10 and in recent decisions in relation to the privilege against self-incrimination, the European Court would seem to be following this route. But the question again arises as to whether a special right against self-incrimination has any

See Allen and Mace (n 6) above.

${ }^{38} R \cup S(R)(1995) 121$ DLR $\left(4^{\text {th }}\right) 589,702-3$, per L'Heureux-Dube J. See also P Arenella, 'Schmerber and the Privilege Against Self-Incrimination: A Reappraisal' (1982) 20 American Criminal Law Review 31.

39 Ferreira v Levin 1996 (1) BCLR 1, 123, para 259, per Sachs J.

40 [2003] 2 SCR 678. 
particular rationale that could not be served by the rights to privacy and silence that we have seen already exist or may be deduced under the Convention. ${ }^{41}$

It would seem to be difficult to justify the privilege against selfincrimination in terms of a self-standing right that should exist independently of the absolute right not to be subjected to cruel, inhuman and degrading treatment and the qualified rights to privacy and the general right of silence. If it is difficult to make out a convincing case for such a substantive right on its own ground, it is equally difficult to make a convincing case for the need for such a privilege in order to safeguard other principles. In the statement quoted above the Court links the privilege with the presumption of innocence. This presumption carries with it an evidentiary obligation on the state to prove the ingredients of the offence charged against the accused but it has also been used to express more diffusely the idea that individuals in the criminal process should be treated as innocent and that intrusive actions should not be taken against them unless there are good reasons to do so. This can include such actions as searching and seizing property, stop and search, arrest and questioning. But it is difficult to link the privilege conceptually with these principles. ${ }^{42}$ Clearly requiring a person to incriminate himself can constitute evidence for the prosecution's case but it does nothing to diminish the high standard of proof required for guilt. Clearly also we should limit the State's ability to take action against us in the criminal process without good reason but the privilege extends beyond these situations entitling individuals to refuse to cooperate with an investigation even where there is reasonable suspicion against them. We might try to link the privilege more closely to the presumption by saying that it expresses the idea that an accused should not have to contribute in any way to the prosecution case at least until there is a prima facie case against him. ${ }^{43}$ In a case brought under article 6(2) of the ECHR, the European Court held that drawing inferences against an accused before there was a convincing prima facie case against him was not permissible, for the effect was then to shift the burden of proof to the defendant. ${ }^{44}$ But the problem again here is that the privilege purports to extend to protecting persons from direct compulsion to incriminate themselves even when there is prima facie or strong evidence against them.

Another argument that the Court makes which is closely tied to the presumption of innocence is that the privilege can help avoid miscarriages of justice. An obvious first problem with this claim is that there is not an exact fit between protection from self-incrimination and protection from wrongful conviction. Much argument has been generated over claims about whether innocent suspects or defendants need the right. Bentham claimed that the right

\footnotetext{
41 For arguments basing the privilege against self-incrimination on the protection of privacy, see D J Galligan, 'The Right to Silence Reconsidered' (1988) CLP 69.

42 Roberts and Zuckerman (n 28) 414-6.

44 Telfner v Austria (2002) 34 EHRR 207.

43 cf RK Greenawalt (n 32).
} 
can never be useful to the innocent. ${ }^{45}$ Bentham was primarily concerned about bars to questioning witnesses in court rather than with the private interrogation of suspects in custody which had not been developed in his day and even he may have conceded that there is a danger of vulnerable innocent suspects making incriminating statements in the coercive atmosphere of the police station. ${ }^{46}$ But according to the European Court, the privilege extends beyond giving immunity to making incriminatory statements to the handing over of documents that were in existence before any criminal charge. Clearly these may be of considerable assistance to the court in determining guilt without any risk of them being used to convict the innocent.

When the argument is confined to the making of incriminating statements in the criminal process, another problem is that as an instrumentalist rationale it risks, more than arguments based on intrinsic merit, counter-arguments being made that far from providing a protection to the innocent, the right jeopardises the conviction of the guilty. In the absence of empirical data either way, the arguments and counter-arguments tend to consist of grossly inflated claims about the effect of the right of silence on the guilty and the innocent without enough attention being given to the procedural context in which the right operates. Taking their cue from Bentham, many critics for example, point to the debilitating effect on the prosecution of allowing the guilty to remain silent when they erect a 'wall of silence' upon being called to account for their actions. Even when it appears that suspects are hiding behind a 'wall of silence', however, there is little evidence to suggest that removal of the right of silence will make much difference to the prosecution's prospects of success. When legislation was introduced in Northern Ireland to permit the courts to draw adverse inferences from silence in certain circumstances, there is some evidence to suggest that this encouraged more to speak to the police and testify but no evidence that this did anything to improve the conviction rates. ${ }^{47}$ Conversely, however, when advocates of the right of silence point to the role that it plays in protecting the innocent, it is almost impossible to provide data on the numbers of innocent persons who might be convicted in the absence of the privilege. ${ }^{48}$

A sophisticated version of an argument which concedes that the right encourages the guilty to be silent but claims that abolition would risk the conviction of the innocent has been put forward by Seidmann and Stein. ${ }^{49}$

45 Even in his own day, these claims were hotly contested, see eg Lord Denman's arguments in the Edinburgh Review in 1824, recounted by Twining (n 27) 105.

46 ibid, $209 \mathrm{n} 83$. For discussion of how Bentham's views have been mis-used by modern advocates of the abrogation of the right of silence in the police station, see W Twining, 'The Way of the Baffled Medic' (1973) 12 JSPTL (NS) 348.

47 See J Jackson, M Wolfe and K Quinn, Legislating Against Silence: The Northern Ireland Experience (Northern Ireland Office, Belfast, 2000).

48 Greenawalt (n 32) 44.

49 D J Seidmann and A Stein, 'The Right to Silence Helps the Innocent: A Game-Theoretic Analysis of the Fifth Amendment Privilege' (2000) 114 Harvard Law Review 431. 
Briefly, the argument is that abolition would encourage the guilty as well as the innocent to speak with the net result that fact finders would find it harder to distinguish the guilty who would tell lies from the innocent who would speak the truth. Consequently, the guilty would pool with the innocent resulting in the fact-finder discounting the exculpatory statements of the guilty and the innocent. Although ingenious, this argument also risks making assumptions that may not be empirically justified. In common with other arguments it tends to make an indiscriminate distinction between two categories of persons - the innocent and the guilty - whereas in fact a number of persons innocent of serious charges may be guilty of other offences or have good reason for hiding things from the police. ${ }^{50} \mathrm{~A}$ fundamental problem with the argument, however, as with all the claims that tend to be made about the right of silence protecting the innocent is that it tends to exaggerate its significance in affecting behaviour. It is true that Seidmann and Stein were able to point to the fact that in the context of the changes permitting inferences to be drawn from silence in England and Wales, these had encouraged more suspects to make statements to the police but again in order to show that this has had a detrimental effect on innocent suspects, there would also need to be evidence to show that this has affected the way fact-finders regard exculpatory statements. ${ }^{51}$ The reality in most jurisdictions as we have seen is that most suspects and defendants do speak to the police or testify, irrespective of whether there is a right of silence or not. Within the context of custodial interrogation, the pressure to speak notwithstanding the right is immense because silence can be seen as an act of non-cooperation with the authorities which can do the suspect little good in terms of decisions that affect his or her liberty or that affect the level of the charge brought. Certainly where policing is organized around interrogation and confession, the failure to speak can be interpreted as a challenge to authority. ${ }^{52}$ As regards silence at trial, there is the risk that whatever comments are made exhorting juries to disregard the accused's failure to testify, juries may penalize defendants for not testifying. If the right of silence does not affect behaviour that much, then it is hard to see it as a great buttress for the innocent. Whatever form the argument for the right of silence takes as a safeguard for the innocent, then, either that it encourages innocent persons to be silent (and thereby saves them from falsely incriminating themselves) or

\footnotetext{
${ }^{50}$ For other objections to the theory based on the fact that it makes assumptions about the way suspects and defendants and fact-finders would act that may not be empirically justified: see G Van Kessel, 'Quieting the Guilty and Acquitting the Innocent: A Close Look at a New Twist on the Right of Silence' (2002) 35 Indiana Law Review 924, 956-960 and R Park and MJ Saks, 'Evidence Scholarship Reconsidered: Results of the Interdisciplinary Turn' (2006) 47 Boston College Law Review 1, 72.

${ }^{51}$ See T Bucke, R Street and D Brown, The Right of Silence: The Impact of the Criminal Justice and Public Order Act 1994 (Home Office, London, 2000) Home Office Research Study no 199.

52 See D Dixon, 'Politics, Research and Symbolism in Criminal Justice: The Right of Silence and the Police and Criminal Evidence Act 1984' (1991) 20 Anglo-American Law Review 27, 38.
} 
that it encourages the guilty to be silent (and thereby marks them out from being pooled with the innocent), in reality it appears to affect very few people in their decision whether to speak or not.

Another problem with basing arguments for the privilege against selfincrimination and the right of silence upon the protection of the innocent is that again as an instrumentalist rationale they are vulnerable to counterarguments that offer compensating mechanisms in exchange for these immunities. ${ }^{53}$ The European Court in Murray endorsed such arguments by permitting adverse inferences to be drawn from silence in certain circumstances. Although the Court conceded that warning suspects about inferences may amount to indirect compulsion, it was prepared to justify this degree of compulsion provided safeguards are built into the system such as providing access to legal advice and at court ensuring that any inferences that are drawn can be justified. These were exactly the arguments that were used to justify the extension of the Northern Ireland legislation permitting inferences to be drawn from silence to England and Wales in 1994. A Royal Commission on Criminal Justice established to address concerns that had been raised by a number of miscarriages of justice concluded by a majority that little would be gained and much might be lost if the right were to go as 'the possibility of an increase in the convictions of the guilty is outweighed by the risk that the extra pressure on suspects to talk in the police station and the adverse inferences invited if they do not may result in more convictions of the innocent. ${ }^{54}$ The difficulty with this approach was that it lent itself open for others to conclude, as the minority argued, that if enough other safeguards were put in place in the police station to protect the innocent suspect, then there would be little need for the right. As the government had already concluded that the balance in the police station had swung too far in favour of the suspect principally as a result of a statutory right of access to legal advice introduced in earlier legislation, ${ }^{55}$ it was able to reject the Commission's majority view and adopt the minority view and press ahead with the changes already enacted in Northern Ireland.

\section{THE RIGHT OF SILENCE AS A NECESSARY CONDITION FOR EFFECTIVE} DEFENCE PARTICIPATION

We have reached the point where it would seem difficult to argue for a distinctive privilege against self-incrimination linked to the right to a fair trial over and above the other protections provided for by human rights instruments. It is hard to see why we should give specific priority to respecting the voluntariness of an accused's decision to hand over or reveal incriminating

53 See S Greer, 'The Right to Silence: A Review of the Current Debate' (1990) 53 MLR 58.

54 Royal Commission on Criminal Justice, Report (1993) Cm 2263, 54.

55 As far back as 1987 it had established a working group to consider how, not whether, the law should be changed. See Report of the Working Group on the Right of Silence (Home Office, London, 1989). 
information over and above respecting an individual's general personal autonomy and freedom of action. Other rationales linked conceptually or instrumentally to principles and objectives associated with a fair trial fail to mark out a close enough connection to these principles and objectives.

This is not to say that there should not be a general right of silence deduced from the right to freedom of expression or linked with other rights such as the right of privacy by the need to prevent undue government restrictions on our personal autonomy. We may also want to give special protection against interferences which compel us to incriminate ourselves and others in the course of a criminal prosecution. But these rights need to be weighed against other interests, in particular the need for citizens to account for their actions in certain circumstances. It has been argued, for example, that it is perfectly legitimate to require people who engage in regulatory activities to account for themselves either to public officials or to opponents in litigation. ${ }^{56}$ Within the criminal justice process there may also be a legitimate aim in requiring persons to account for themselves in order to reach a conclusion as to whether a criminal offence has been committed. Applying a strict proportionality test we should only require persons to account for themselves when certain proportionality conditions are fulfilled such as rationality and necessity. ${ }^{57}$ Just as the right of silence can be grossly exaggerated as a mechanism for protecting the innocent, we have seen that it can also be grossly exaggerated as an obstacle for convicting the guilty. Irrespective of whether there is a right of silence or not, there are good prudential reasons why suspects and defendants would want to provide an account of themselves. Of the few who would be affected by an abrogation of the right and change their behaviour by providing an account, it is unclear how advantageous their speaking is to the police or the prosecution.

Hence in general terms we should not require suspects to account for themselves. Exceptions might be made in cases where it is might otherwise be difficult to find the necessary evidence such as in road traffic cases of the kind that arose in O'Halloran and Francis where the owner of a car was required to name who had been driving his car at a particular time when it was seen to be exceeding the speed limit. ${ }^{58}$ But it is not enough in these

\footnotetext{
56 S Sedley, 'Wringing out the Fault: Self-Incrimination in the $21^{\text {st }}$ Century' (2002) 52 Northern Ireland Legal Quarterly 107.

${ }^{57}$ See eg R Alexy, 'The Structure of Constitutional Rights Norms' in A Theory of Constitutional Rights (Oxford University Press, Oxford, 2002) arguing that constitutional rights are optimization requirements that ought to be realized until competing considerations can justify their limitation according to strict proportionality conditions.

58 Redmayne (n 31) 230. cf Brown v Stott [2001] 2 WLR 817 where the Privy Council held that an admission compulsorily obtained under road traffic legislation by the defendant that she had been driving her car did not violate her right to a fair trial. The Privy Council held that limited qualification of the right against self-incrimination was acceptable if it was reasonably directed towards a clear and proper objective and represented no greater qualification than was called for by the situation.
} 
situations, arguably, just to claim that the right of silence can be 'balanced away' by a general public interest such as the need to subject more vehicles and their owners to a strict regulatory regime. ${ }^{59}$ There would in addition have to be specific reason to show why requiring motor owners to name drivers was necessary in order to achieve this aim. On this reasoning, pace the ruling in the Saunders case, there may also be circumstances where enforced answers made outside the criminal context should be allowed to be presented as part of the prosecution case. But again these would need to be strictly justified on the bases of rationality and necessity, taking account of all reasonable alternatives. ${ }^{60}$

Short of compelling a person to give evidence or answer questions in the criminal process, however, once there is a basis in evidence for suspecting that a person has been engaged in criminal conduct, it would seem reasonable to call for an answer not out of necessity in order for the prosecution to make out its case (the need for the prosecution to obtain answers from a suspect can as we have seen be greatly exaggerated) but rather to advance the general interests of truth finding within what may be called the 'adversarial' rationalist tradition. ${ }^{61}$ Although traditionally this mode of fact-finding has been reserved for the trial, states are increasingly 'front-loading' the forensic enterprise into the pre-trial phase in order to expedite proceedings and there is no reason why this should not be done provided suitable safeguards are put in place. Safeguards are necessary to ensure that suspects are not put under improper physical or psychological pressure and that they are able to put forward any defence as effectively as they can. At the point when there is a basis in evidence for putting allegations against a suspect, he or she ought arguably to be given the same or equivalent defence rights as are available at trial which include, most importantly, access to legal advice, disclosure of the evidence against him and an authenticated record of any interview either by audio or video tape. But such safeguards cannot be effective unless they are accompanied by a Miranda-style rule prohibiting any questioning until they are put in place and because as we have seen suspects are inevitably put under pressure when faced with criminal allegations, especially when they are in custodial interrogation, suspects in custody should not be able to waive these rights, at least not until they have had an opportunity to speak to a lawyer. Once there is sufficient evidence of a person's involvement in a criminal offence, the right of silence should arguably be given greater salience than in

59 A Ashworth, Human Rights, Serious Crime and Criminal Procedure (Sweet \& Maxwell, London, 2002) 65, criticizing the Brown decision for putting the privilege against selfincrimination second to the general public interest.

${ }^{60}$ cf Ferreira $v$ Levin 1996 (1) BCLR, 1, para 265, per Sachs J (doubting whether these conditions were met where examinees' compelled answers to questions in an inquiry into a company's affairs could be used against them in subsequent criminal proceedings).

${ }^{61}$ For the claim that most Anglo-American evidence scholarship has been dominated by a rationalist tradition which gives overriding effect to rectitude of decision making, see $\mathrm{W}$ Twining, Rethinking Evidence (2 ${ }^{\text {nd }}$ edn, Cambridge University Press, Cambridge, 2006) chapter 3. 
other encounters between the State and the citizen by preventing any questioning until safeguards are put in place to enable the accused to mount an effective defence. When these are in place, the right of silence would still be respected in the sense that suspects would not be compelled to answer police questions but as at trial they would be given the opportunity to respond to the allegations against them. It is doubtful also whether at this stage there is any need to apply the 'indirect compulsion' of warning suspects that adverse inferences may be drawn against them. Suspects would be made aware, however, that they have an opportunity to respond to certain allegations that have arisen against them and that a record will be made of any answers for the purposes of trial. In recognition of the growth in non-judicial and non-court disposals across a number of jurisdictions, ${ }^{62}$ they would also be made aware through access to a lawyer of any informal disposals or decisions that may be made if they are prepared to make an admission to the allegations.

On this analysis the right of silence would be maintained throughout the stage of police investigation because it is not generally necessary for the investigation for suspects to be compelled to give evidence. At a point when there are allegations based on evidence that call for an answer, suspects should, however, be given an opportunity to respond under conditions that allow for informed and fair participation. These conditions which would still caution suspects that they have a right not to respond are required not out of any sentimental desire to see 'fair play' or to give suspects a 'sporting chance' to avoid conviction but out of a need to enable suspects to participate effectively in the proceedings that have in effect been mounted against them. Of course, under legal advice suspects may decide as at trial not to answer questions. But this decision would be an informed one after they have been told, for example, that there may be costs attached to such a strategy in terms of delayed disposal of the case. ${ }^{63}$ It would also be a decision made with the

${ }^{62}$ See S Thaman, 'Plea-Bargaining, Negotiated Confession and Consensual Resolution of Criminal Cases' in K Boele-Woelki and S van Erp (eds), General Reports of the XVII Congress of the International Academy of Comparative Law (2007). For the effect of recent non-court disposals on suspects in custody such as the use of conditional cautions in England and Wales whereby defendants who admit their guilt are offered the chance to agree to complying with certain conditions as an alternative to appearing in court, see J Jackson, 'Police and Prosecutors after PACE: The Road from Case Construction to Case Disposal' in E Cape and R Young (eds), Regulating Policing The Police and Criminal Evidence Act Past, Resent and Future (Hart, Oxford, 2008) 255.

63 Although there are limits to the incentives that should be offered to suspects to cooperate, arguably it is unrealistic for any legal system which with limited resources must try to expedite proceedings as much as possible not to offer certain incentives to suspects to cooperate with an investigation. The ICTY Chamber has held that the lack of cooperation of an accused should not as a rule be taken into consideration as a factor that might justify denial of an application for provisional release. See Prosecutor v Jokic IT-01-42-PT and IT-01-46-PT, Orders on Motions for Provisional Release, 20 February 2002. But cooperation with the prosecution can be cited as a mitigating factor at the sentencing stage: see W Schabas, The UN International Criminal Tribunals: the Former Yugoslavia, Rwanda and Sierra Leone (Cambridge University Press, Cambridge 2006) 532-533. 
full participation of an active defence. The decision not to answer questions would be a negative one but again as at trial it would be made as part of an active defence strategy on the basis of equality of arms.

We have reached the point then where it would seem justified to give the right of silence a special weighting for suspects in the criminal process and for this to be considered part of the right to a fair trial. It is not helpful, however, to link such a right with the privilege against self-incrimination in so far as this suggests that just because they are suspects they should be given some special or absolute immunity from disclosing information that may indicate their guilt. A better ground for justifying a 'weighted' right of silence for suspects is that there needs to be a recognition, especially where suspects are in custodial interrogation, of the vulnerable position that they are in and of the need therefore to avoid the risk of false confession. ${ }^{64}$ When persons such as the applicant in the Saunders case are required to provide information to noncriminal investigators, they are often given advanced notice in writing of what is required of them and positively advised to have a legal adviser present. A police interview with a person in custody may take a very different form. ${ }^{65}$ It is certainly arguable that in this situation the potential for systemic abuse of law enforcement powers is at its greatest.

Our argument for an enhanced right of silence at this stage, however, goes beyond simply an instrumentalist need to avoid persons falsely incriminating themselves. As well as providing a protection for the innocent it may be argued that the right is justified as a necessary procedural part of the general rights of the defence to enable the suspect to mount an effective defence. Commentators are increasingly making a distinction between protective and participative defence rights. ${ }^{66}$ The right of silence has tended to be classified as a protective right, although on our argument unless it is transformed in the custodial context into a right not to be questioned akin to the accused's right not to be questioned at trial, it is unable to perform an effective protective function. On our view, however, it ought also to be viewed more positively as part of the framework for the exercise of effective defence rights. Once under criminal suspicion, accused persons are entitled to be given the opportunity to defend themselves but in order to do this effectively, the rights of the defence need to be put into place before they are asked to provide a defence. Just as at trial, so in the pre-trial phase, suspects should be given an opportunity to

64 See A Ashworth and M Redmayne, The Criminal Process ( $3^{\text {rd }}$ edn, Oxford University Press, Oxford, 2005) 94, P J Schwikkard, 'The Muddle of Silence' (2009) 6 International Commentary on Evidence issue 2.

65 See J Jackson, 'The Right of Silence: Judicial Responses to Parliamentary Encroachment' (1993) 57 MLR 270, 274, Dennis (n 26) 370.

66 See, eg A Roberts, 'Pre-Trial Defence Rights and the Fair Use of Eyewitness Identification Procedures' (2008) 71 MLR 331, J Jackson, 'The Effect of Human Rights on Criminal Evidentiary Processes: Towards Convergence, Divergence or Realignment?' (2005) 68 MLR 737. See also Summers (n 9) who makes a distinction between the rights of the accused and the institutional position of the defence. 
mount their most effective defence and this requires that there should be no questioning of suspects until such time as the conditions for this are put in place, principally by giving access to legal advice which is necessary so that decisions as to how to mount the defence are, just as at trial, taken on an informed basis. Various options as at trial are available at this stage. One may simply admit to the allegations that are being put. One may answer police questions or, depending on the procedure submit to judicial inquiry. Another, option may be to offer a detailed written explanation of one's conduct or to suggest certain lines of exculpatory inquiry.

\section{INCORPORATING FAIR TRIAL STANDARDS FROM THE POINT OF BEING CALLED}

TO ACCOUNT

Since on our argument then proceedings have effectively begun against suspects as soon as they are to be called to account for evidence against them, then they should be entitled at that point to all the fair trial safeguards that are provided under the ECHR and other international standards. This is the point indeed at which the international criminal tribunals recognise that defence rights come into play. Article 14 of the ICCPR which includes a right not to be compelled to give evidence was expressly incorporated into the Statutes of the ad hoc international tribunals at The Hague and Arusha. ${ }^{67}$ In addition the Statutes require that if questioned by the prosecutor, the suspect has a right to the assistance of legal counsel provided for free if he does not have the means to pay and the right to any necessary translation. ${ }^{68}$ The rules go further by requiring that suspects are informed of these rights before being questioned and in addition are informed of the right to remain silent, and to be cautioned that any statement that is made shall be recorded and may be used in evidence. ${ }^{69}$ Somewhat akin to the Miranda rules, ${ }^{70}$ the rules further require that questioning of a suspect should not proceed without the presence of counsel

67 ICTY Statute Art 21, ICTR Statute art 20.

68 See ICTY Statute art 18(3), ICTR Statute art 17 (3). The inclusion of this latter right was added to the rules in 1995 out of recognition of its importance: see J R W D Jones and S Powles, International Criminal Practice ( $3^{\text {rd }}$ edn, Oxford University Press, Oxford, 2003) 502.

69 ICTY, ICTR RPE 42A.

70 Note though the difference in that the Miranda rights only extend to a right to the presence of an attorney prior to questioning whereas the international criminal tribunals extend this right to the presence of counsel during questioning. This marks an important difference of perception in the way the right to counsel is exercised. Once a suspect exercises his Miranda rights, it would seem American defence lawyers virtually always advise suspects not to talk to the police, an attitude immortalized in Justice Jackson's comment that '[A]ny lawyer worth his salt will tell the suspect in no uncertain terms to make no statements to the police under any circumstances': Watts v Indiana 338 US 49, 59 (1949). See G Van Kessel, 'European Perspectives on the Accused As a Source of Testimonial Evidence' (1998) 100 West Virginia Law Review 837. The way the right is expressed in the international criminal tribunals' statutes and rules, however, suggests that defence lawyers have at this stage a more positive role to play in participating in the defence. 
unless the suspect has voluntarily waived his right to counsel. ${ }^{71}$ In addition all interviews must be recorded by audio or video-tape. ${ }^{72}$ The ICTY Trial Chamber has also recognized the principle that where statements have been obtained by national authorities in breach of these safeguards, they may not be able to be admitted. ${ }^{73}$ The ICC Statute goes further by granting certain basic safeguards to any persons who are subject to questioning at any time during an investigation under the Statute including the privilege against selfincrimination, the right not to be subjected to any form of coercion, duress or threat, to torture or to any other form of cruel, inhuman or degrading treatment or punishment and rights to translation. ${ }^{74}$ Then where there are grounds to believe that a person has committed a crime within the jurisdiction of the court and that person is about to be questioned either by the Prosecutor or by national authorities conducting an investigation under the Statute, he shall be informed of his defence rights which in addition to the rights under the ad hoc tribunals require that he be informed prior to being questioned of which crimes he is suspected of. ${ }^{75}$ Although these rights do not go quite as far as the optimal rights granted to accused persons at trial, they establish an important basis for an equality of arms in the pre-trial phase of proceedings at the stage when accusations are made against suspects.

The European Court has been somewhat unclear as to when defendants are 'charged' for the purposes of Article 6 of the ECHR so as to enable their defence rights to come into play. It has considered that defendants are engaged within the meaning of article 6 when they have been officially notified of an allegation or 'substantially affected' by the steps taken against them. ${ }^{76}$ It has been argued elsewhere that the mere exercise of investigatory powers against a suspect should not in itself trigger the initiation of proceedings but that proceedings do commence when defendants are held to account for allegations. ${ }^{77}$ If this is the point at which a defendant is charged, his defence

71 ICTY, ICTR RPE 42B.

72 ibid 43.

3 Prosecutor v Delalić et al, Decision on Mucić's Motion for the Exclusion of Evidence, 2 Sept 1997 (excluding statements obtained by Austrian police in circumstances where the accused was not offered counsel or informed adequately of his rights). See R May and M Wierda, International Criminal Evidence (Transnational Publishers, New York, 2002) 277-278.

74 Rome Statute of the ICC, Art 55(1).

75 ibid Art 55(2).

76 Deweer v Belgium (1980) 2 EHRR 439 at [46]; Eckle v Federal Republic of Germany (1983) 5 EHRR 1. The UK courts have been similarly unclear on this point. In Attorney General's Reference (No 2 of 2001) the House of Lords held that the point in time at which proceedings should commence should ordinarily be when the accused is formally charged or served with a summons. But in $R$ (on the application of $R$ ) $v$ Durham Constabulary and Another [2003] 3 All ER 419, [2005] UKHL 21 the Divisional Court accepted that Art 6 was engaged when a person had been formally notified that allegations against him were being investigated. In the House of Lords Lord Bingham expressed reservations as to whether this was correct but was prepared to assume with some reluctance that there was a criminal charge against the young person at the beginning of the process by which he appeared to mean at the point of arrest.

77 J Jackson, 'The Reasonable Time Requirement: an Independent and Meaningful Right?' [2005] CLR 3, 19. See Howarth v United Kingdom (2000) 31 EHRR 861, Quinn v Ireland (2001) 33 EHRR 264. 
rights under article 6 are then triggered and he should be entitled to the full panoply of equality of arms including the presence of a legal adviser when being questioned and, something that is not presently provided as of right, disclosure of the case against the defendant as well. ${ }^{78}$

If the European Court has been less than clear as to when exactly a person is charged for the purposes triggering Article 6 rights, it has also been less than unequivocal about the importance of defence rights in the pre-trial phase of proceedings. In Imbrioscia $v$ Switzerland ${ }^{79}$ the Court accepted the principle that a defendant should have a right to assistance by counsel during police interrogations, although in the instant case it held that there had been no breach of article 6 because the applicant's lawyer had not asked to be present. This makes it clear that it is up to the defence to activate the right to be present at the examination of the accused. ${ }^{80}$ Moreover the principle is somewhat weakened by the fact that the Court considered that there is no breach of article 6 unless the fairness of the trial is seriously prejudiced by an initial failure to comply with its provisions. In its own words, 'the manner in which article $6(3)(\mathrm{c})$ was applied during the preliminary investigation depended on the special features of the proceedings involved and on the circumstances of the case. ${ }^{81}$ These observations were repeated in John Murray where the Court recognized the importance of legal advice being made available to suspects when warned about the possibility of adverse inferences being drawn against them. According to the Court in this case: ${ }^{82}$

\begin{abstract}
National laws may attach consequences to the attitude of an accused at the initial stages of police interrogation which are decisive for the prospects of the defence in any subsequent criminal proceedings. In such circumstances Article 6 will normally require that the accused be allowed to benefit from the assistance of a lawyer already at the initial stages of police interrogation. However, this right, which is not explicitly set out in the Convention, may be subject to restrictions for good cause. The question, in each case, is whether the restriction, in the light of the entirety of the proceedings, has deprived the accused of a fair hearing.
\end{abstract}

This is a less than ringing endorsement of the right to legal assistance in the pre-trial phase of criminal proceedings. Three qualifications appear to be made. First of all, the Court appeared to link the need for legal advice instrumentally with the consequences that may later attach to suspects at their trial from decisions made at the pre-trial phase. In John Murray the consequences of the decision not to answer questions were the possibility of adverse inferences being drawn from this at trial. In the later case of Magee $v$ United Kingdom ${ }^{83}$ the applicant was detained and his access to legal advice

\footnotetext{
${ }^{78}$ See eg R J Toney, 'Disclosure of Evidence and Legal Assistance at Custodial Interrogation: What does the European Convention on Human Rights Require?' (2001) 5 International Journal of Evidence \& Proof 39.

${ }^{80}$ Trechsel (n 24) 267.

82 (1996) 22 EHRR 29, para 63.

79 (1994) 17 EHRR 441.

81 (1994) 17 EHRR 441, para 38.

83 (2001) 31 EHRR 35.
} 
was also delayed for 48 hours. He was cautioned under the same legislation that was used to draw adverse inferences against the applicant in the John Murray case but unlike Murray, the applicant in this case broke his silence in his sixth police interview. The prosecution case against him was then based on the admissions that he made in interview. Having reiterated the principles set out in Imbrioscia and John Murray the Court considered the conditions in which the applicant was held in custody and took the view that as a matter of procedural fairness, he should have been given access to a solicitor at the initial stages of the interrogations 'as a counterweight to the intimidating atmosphere specifically devised to sap his will and make him confess to his interrogators'. ${ }^{84}$ The caution delivered to him under the legislation was an element which heightened his vulnerability. The Court concluded that to deny access to a lawyer for such a long period and in a situation where the rights of the defence were irretrievably prejudiced was - whatever the justification for such denial - incompatible with the rights of the accused under article $6 .{ }^{85}$ While the domestic court found on the facts that the applicant had not been ill-treated and that the incriminating statements he had made were voluntary, those that he had made by the end of the first 24 hours of his detention became the central platform of the prosecution's case and subsequently the basis for the applicant's conviction.

There is little doubt that the consequences of the applicant's decision to confess in this case were no less decisive for the outcome of the case than the consequences of the applicant's decision to remain silent in the John Murray case. The need for the applicant to have access to legal advice before making such a significant decision was therefore very strong. But it has been suggested that the behaviour of the suspect immediately after arrest will always have consequences. ${ }^{86}$ If the accused makes a statement then even if this cannot be later used in evidence, it will be recorded in the continental system and joined to the file. In the course of the proceedings it may then be quoted in order to clarify contradictions between that and later statements. Even under the US Miranda system statements made in the absence of a lawyer may be used later to impeach testimony. If the suspect decides to be silent, then it will be hard especially in the continental system for this to be kept later from the triers of fact. Under common law systems it may be easier to keep such evidence from the jury but many systems have permitted the prosecution to lead evidence of how a defendant has reacted to questions and to allow comment along the lines that a particular defence was first put forward at trial. ${ }^{87}$ More

${ }^{84}$ ibid para 43.
${ }^{87}$ See $R v$ Gilbert (1977) 66 Cr App R 237. In a study conducted for the Royal Commission on Criminal Justice in 1993 it was found that the jury heard about the defendant's silence under questioning in 80 per cent of Crown Court trials. See M Zander and P Henderson, Crown Court Study (London, HMSO 1993), RCCJ research study no 19. In Canada it seems that efforts are made to shield the jury from an accused's pre-trial silence except where it has special relevance, see DM Paccioco and L Stuesser, The Law of Evidence (4 ${ }^{\text {th }}$ edn, Irwin, Toronto, 2005) 288-289. 
broadly, it may be argued that whatever use is made of the suspect's responses or lack of them at a later trial, the suspect's reaction may have a considerable effect on the way the case is investigated and whether it is prosecuted or disposed of by other means.

The second qualification is that even in circumstances when decisions are made at the pre-trial stage which have consequences at trial, it would seem that restrictions may be placed on access to legal advice 'for good cause'. Under the Northern Ireland legislation access could be denied to terrorist suspects for 48 hours if there was a risk of alerting persons suspected of involvement in the offence who were not yet arrested. In Magee it was considered that whatever the justification, the restriction in this case could not be compatible with article 6 given the fact that the rights of the defence were so irretrievably prejudiced. But the Court left it open in other cases to consider that there may be just cause to restrict access, perhaps where the coercive atmosphere of the interrogation was less pronounced or where the defendant was not facing such serious charges. ${ }^{88}$ The final qualification made in the above statement is the familiar resort that we have seen the Court takes to looking at the proceedings as a whole before deciding whether there has been a breach of article 6 . This has been used in certain cases to uphold the fairness of trials even where there has a systemic denial of access to a lawyer at the pre-trial phases. In one case where the applicant had been in custody for 20 days without seeing a lawyer, the Court took note of the fact that at trial he had the benefit of legal assistance and that he had enjoyed, 'overall', a fair trial. $^{89}$

In its latest decisions the European Court would seem to have given stronger expression to the need for suspects to avail of legal advice before being questioned, although it has repeated the qualifications made by it in John Murray. In Salduz v Turkey ${ }^{90}$ the applicant had been interrogated in the absence of a lawyer after signing a form reminding him of the charges against him and of his right to silent. He made various admissions to the police of being involved in an unlawful organization and hanging an illegal banner from a bridge. He later retracted his statement to the police alleging that it had been extracted under duress. His statement was used for the purpose of his conviction and in concluding that there had been a breach of article 6 the Court held that he had been undoubtedly affected by the restrictions on his access to a lawyer. The Court expressly linked the right of access not only to the need to protect the accused against abusive conduct on the part of the authorities and

88 cf Brennan v United Kingdom (2002) 34 EHRR 18 where the Court considered deferral was in good faith and on reasonable grounds but in any event the admission was made after the deferral of access and could not be linked to it.

${ }^{89}$ Sarikaya v Turkey, Application no 36115/97, 22 April 2004. See also Mamaç v Turkey, Application nos 29486/95, 29487/95, 29853/96, 20 April 2004. Cf Ocalan v Turkey (2003) 37 EHRR 10.

90 Application no 36391/02, 27 November 2008. 
the prevention of miscarriages of justice but also to fulfilment of the aims of article 6 , notably 'equality of arms between the investigating or prosecuting authorities and the accused'. ${ }^{91}$ The Court underlined the importance of the investigation stage for the preparation of the criminal proceedings as the evidence obtained during this stage determines the framework in which the offence charged will be considered at the trial. At the same time, the Court continued, 'an accused often finds himself in a particularly vulnerable position at that stage of the proceedings, the effect of which is amplified by the fact that legislation on criminal procedure tends to become increasingly complex, notably with respect to the gathering and use of evidence' ${ }^{92}$ As a result in most cases this particular vulnerability can only be properly compensated for by the assistance of a lawyer whose task it is, among other things, to help ensure respect of the right of an accused not to incriminate himself which presupposes that the prosecution in a criminal case seek to prove their case against the accused without resort to evidence obtained through methods of coercion or oppression in defiance of the will of the accused. Against this background and against the repeated statements of the European Committee for the Prevention of Torture and Inhuman or Degrading Treatment or Punishment that the right of a detainee to have access to legal advice is a fundamental safeguard against ill treatment, the Court found that in order for the right to a fair trial to remain sufficiently 'practical and effective' Article 6 (1) required that, as a rule, access to a lawyer should be provided as from the first interrogation of a suspect by the police, unless it is demonstrated that in the light of the particular circumstances of each case there are compelling reasons to restrict this right. ${ }^{93}$ Even then the rights of the defence must not be unduly prejudiced and the Court went on to say more unequivocally than it did in Magee that the rights of the defence will in principle be irretrievably prejudiced when incriminating statements made during police interrogations without access to a lawyer are used for a conviction.

This judgment is to be welcomed for putting the right of access of a lawyer on a firmer footing emphasising not only the protective role that the lawyer can play in ensuring that detained persons are not coerced into making a confession in breach of the privilege against self-incrimination but also the positive participative role that is required in advising on the complexities of gathering and using evidence. ${ }^{94}$ This is emphasised particularly in the concurring opinions of Judge Zagrebelsky with Judges Casadevall and Turmen and of Judge Bratza who would have preferred the Court to have emphasized that detained persons should be entitled to access to legal assistance not just from the point of interrogation but as soon as they are imprisoned so that from that stage they can give their lawyer instructions in order to prepare their defence. The Court emphasizes the important impact which the investigation stage

\footnotetext{
91 ibid para 53. $\quad 92$ ibid para 54. 93 ibid para 55.

94 Salduz has applied in a number of recent cases see Panovits v Cyprus, Appln. no
} 
may have for the trial but the reality is that increasing numbers of cases in many jurisdictions do not reach trial at all. This makes it all the more important, however, that accused persons are given access to a lawyer before the first stages of interrogation as in many cases it is this first encounter with the police that may determine whether the case is advanced to trial or is otherwise diverted out of the court process. Another useful aspect of the judgment is that it emphasises that if defence rights are to be waived, any waiver must be established in an unequivocal manner and be attended by minimum safeguards commensurate to its importance. ${ }^{95}$ Thus in the present case no reliance could be placed on the assertion in the form that the applicant had been reminded of his right to silent. It may be argued indeed that to be effective any waiver must be witnessed by a lawyer or a judicial figure rather than simply be made in the presence of the police.

\section{CONCLUSION}

In this article we have argued that although human rights standards and jurisprudence have linked the privilege against self-incrimination with the right of silence as an essential ingredient of a fair trial, it would be better in the context of fair trial rights to make a distinction between the two. While in general terms these rights may be viewed as part of the need for states to respect the individual dignity and autonomy of the individual, it is indisputable that there are circumstances when they may have to give way to other considerations when states need access to information. We have argued, however, that within the criminal process the right of silence is entitled to be given a special weighting not specifically for reasons to do with upholding substantive rights such as the dignity and respect of the individual but in order to uphold the procedural rights of the defence which it has been argued come into play not just at the trial phase of criminal proceedings but also at the stage of pre-trial proceedings when a suspect is called upon to answer allegations against him.

Human rights jurisprudence has developed special participatory rights for the defence such as the equality of arms and the right to adversarial procedure at the trial phase of proceedings. It would seem only logical that these principles are also applied at the pre-trial phase when the defendant is equally affected by the proceedings by being asked to participate in them. If it is important for a defendant to be given full access to the rights of the defence at the stage when he or she is asked to account for allegations in order to mount the most effective defence, then it is important that these rights are in place at this stage and that a defendant is not called to account for actions until they are in place. The right of silence should be transformed at this stage of the criminal process from a right which is linked to the exercise of an individual's

\footnotetext{
95 See also Panovits v Turkey, Appln. no 4268/04, 11 December 2008.
} 
will but is extraordinarily difficult to assert in the coercive atmosphere of a police station and should become instead a procedural right inextricably linked to the participatory rights of the defence by requiring that there can be no participation by the accused until the conditions for fair and informed participation are put in place. In order to further highlight the distinction between these two aspects of the right of silence, one predicated upon the exercise of will and the other linked institutionally with the rights of the defence, it can be argued that accused persons should not, at least in the most serious cases, be able to able to waive their defence rights without at least having consulted with a solicitor. Defence rights exist arguably not just out of respect for the dignity of the individual but to safeguard institutional values that are held dear in the criminal process such as the need for accurate findings of fact and the protection of the innocent. Once the rights of the defence are put in place, however, the right of silence reverts to an exercise of will or choice on the part of the individual accused, but a choice that is made on an informed basis as part of a defence strategy which is taken in full recognition of the costs and benefits of its exercise. 